\title{
Educational Institutions of Egyptology in Egypt the 1865 - 1928
}

\author{
Enas Fares Yehia \\ Lecturer - Tourism Guidance Department \\ Faculty of Tourism and Hotels - Minia University
}

\begin{abstract}
The study of the Egyptians to Ancient Egypt; its religion, history, and language flourished long before the earliest European Renaissance contact, contrary to the prevailing view that the Egyptians had no interest in Ancient Egypt. Sources indicate that not only a keen interest, but also serious study that seeks to understand and benefit from the study of Ancient Egypt, although this type of Education was sponsored by Europeans who concentrated their efforts in teaching this science, the Egyptians were aware about the importance of gaining information relating for their heritage to protect it, so a number of Egyptian figures appeared in this field like, Ahmed Kamal Pasha, Ahmed Naguib, and Selim Hassan. Although Egyptology was not from the priorities of the Egyptian rulers in Modern Egypt, there were many educational centers devoted for teaching Egyptology, started from the era of Mohamed Ali and flourished during the era of khedive Ismail. The article started by 1865 as the real start was by the foundation of Madrast El Lesan Al Masry Al Qadeem in 1865, and ended by 1928 as the first class graduated with a license was in 1928 which was one of the most important educational centers for Egyptology. This article discusses the stages of the Educational institutions which devoted for studying Egyptology in Egypt under the monarchy era, and the obstacles faced this type of education and how it was solved.
\end{abstract}

Keywords Archeology, Egyptology, Education, Monarchy Era.

\section{Introduction}

Egyptology is a problematic term, because if it was taken literally it would mean the study of all aspects of Egypt, climate, language, geography, geology, society, and culture, not just its ancient history but all of its history from the earliest times to the present day. Actually, what Egyptology means is the study of Ancient Egypt from the beginning of Egyptian recorded history till the advance of the Greco-Roman period. An Egyptologist is a specialist in Ancient Egyptian language, art, archeology, and history, but by no means is everyone who studied ancient Egypt is an Egyptologist. ${ }^{1}$

1 Jason Thompson, Wonderful Things: A History of Egyptology 1 from Antiquity to 1881, vol.1, (A.U.C press, Cairo,2015), p.1-2. 
Egypt entered the zone of European influence after the French expedition. The cultural impact of the French campaign into Egypt was tremendous. The discovery of the Rosetta stone by the French, enabled French scholars to decipher the sacred hieroglyphic language, an interest by Egyptians and others then developed in the ancient history of Egypt, the science of Egyptology began from that period. ${ }^{2}$ Thus, The French expedition was the first who returned the eyes of the world by the importance of Egypt's monuments.

The colonial domination of the study of Egyptology continued unpopular but unchallenged throughout the $19^{\text {th }}$ and the $20^{\text {th }}$ centuries. The scientific work of the Institut d'Egypte, set up by Napoleon published monographs, and an annual Bulletin which carried articles on archeology, but not only rarely were contributions by Egyptians included in comparison with those in other areas of science. ${ }^{3}$

Many Egyptians were preoccupied with their own circles of Arabic Islamic learning, but AlTahtawi, Ali Mubarak and Astronomer Mahmud Al Falaki encouraged their countrymen to participate in this western domination, but potentially universal institutions of expanding knowledge. Al Tahtawi, and Ali Mubarak were involved in Egyptology under the reign of Khedive Ismail. Despite the Varity of schools built during the reign of Mohamed Ali, they were away from teaching Egyptology. The two men started thinking not only in terms of Islamic loyalty, but also of an Egyptian nation rooted in the pharaonic past. In Al Tahtawi's youth Quran schools and Al Azhar were almost the only formal schooling available, but his mission to Paris in 1826 enabled to add him a liberal education in France. ${ }^{4}$

Constructing a specialized school or institute for teaching Archeology and Egyptology was considered an important matter, to reveal the secrets of the Ancient Egyptian civilization, despite the scarcity of sources which refer to educational institutions for teaching Egyptology during the era of Muhammad Ali, but it was said that he issued an order for constructing a school for teaching both history and geography, worth mentioning that it was not a school in the name but it was just a class inside El Madfaia school. This means that this type of education of teaching the ancient was known from Muhammad Ali's era, this class was unsatisfied for Al Tahtawi who declared the necessity of establishing an institution for teaching all what related to ancient Egypt. ${ }^{5}$

In 1838-1839 Abdullah Abu Alsuuid and two of Al-Tahtawi's other students had translated a French history of Ancient Egypt into Arabic as Bidayat Al Qudmaa (Primer of the Ancients). Al Tahtawi revised it and added a preface, Abu al-suud returned to the subject in 1864-1865 with his translation of Mariette's Apercu de L'histoire d'Egypte depuis les temps les plus recules jusqu'a la conquite musulnone. Abu Alsuud explained, 'because the khedive wants to waken us from this torpor by the study of our ancestors so that we can revive their glorious virtues and follow their example in working together as the Egyptians and true patriots for the renaissance of Egypt'. Al Tahtawi imagined his history of Ancient Egypt, Anwar Tewfik Al Jalil fi Akhbar Misr wa Tawthiq Bani Ismail (Glorious light on the story of Egypt and authentically of the sons of Ismail, as the

${ }^{2}$ Youssef M. Choueiri(ed.), A Companion to the History of the Middle East, (Blackwell Publishing Ltd., Oxford, 2005), p. 241.

${ }^{3}$ Jason Thompson, Wonderful. A History of Egyptology from Antiquity to 1881, p. 9

4 Donald Malcolm Reid, Whose Pharaos?: Archeology, Museums, and Egyptian National Identity from Napoleon to World War I, (University of California press,2002 ), p.96.

${ }^{5}$ Charles Kurzman(ed.), Modernist Islam 1840-1940, ( Oxford University press, 2002), p.31. 
first volume of a longer survey, the volume covered the pharaonic, Greco-Roman, and Byzantine eras up to the Islamic conquest. Al Tahtawi followed reign by reign through Manetho, thirty dynasties with thematic summaries at the end of each era, he noted that the Europeans decipherment of hieroglyphics had revealed the correct names of the three pyramid builders of Giza, though whether they came before or after Abraham was still in dispute. Al-Tahtawi followed Mariette in pointing out where evidence from the monuments confirmed, augment or contradicted Greek literary sources. ${ }^{6}$

These trials were made by individual's interest and not as an organized educational system from the Egyptian government, the real start for teaching Egyptology for the Egyptians was by the foundation of Madrast El Lesan Almasry Alqadeem.

\section{Madrast El Lesan Almasry Alqadeem (School of the Ancient Egyptian Language)}

Khedive Ismail and his minister of Education Ali Mubarak set up a specialized school of Egyptology, they wanted to produce Egyptologists to work a long side Europeans in the Egyptian museum and antiquities service, Mariette opposed this fearing for his own position. FranceGerman rivalry however opened a crack in European solidarity, enabling Egyptians to try studying Egyptology. In 1865 Ali Mubarak offered the German Egyptologist Brugsch a contract to lead the School of Egyptology, for five years. He was given a high salary, together with a large house with a beautiful garden, this mean that he was well respected by the Egyptian government ${ }^{7}$.

\section{Its Students}

This school was consisted of ten students only; Mohamed Tewfik, Ahmed Naguib, Ali Gaid, Mohamed Fakhry, Mohammed Esmat, Mohamed Wasfi, Ebrahim Naguib, Ahmed Hassan, Hussein Zaki, Ahmed $\mathrm{Kamal}^{8}$. Khedive Ismail wanted to form the students from upper Egypt with their brown skin, as most of Egypt's monuments are located in upper Egypt ${ }^{9}$.

Regarding the subjects, the students of this school taught the Hieroglyphics by the hands of Brugsch himself, who took them into field trips to see the monuments in Upper Egypt, he tried to teach the students all what related to the life of the ancient Egyptians ${ }^{10}$. His ideas on the ancient Egyptian religion were similar to those of Refaa Al Tahtawi, in that he believed the titles of the ancient Egyptian gods proved that a single divine being underlay these epithets.

In this school, also the students study German by Emile Brugsch, Michael from Orthodox Church taught them the Coptic language ${ }^{11}$. Inside it also they learned both English and French, it seems that they were prepared to be tour guides.

\footnotetext{
${ }^{6}$ Donald Malcolm .Reid, Whose Pharaos?: Archeology, Museums, and Egyptian National Identity from Napoleon to World War I, p. 188.

${ }^{7}$ Heinrich Brugsch, Mein Leben Und Mein Wandern,(Berlin, 1894), p. 46.

${ }^{8}$ Heinrich Brugsch, Mein Leben Und Mein Wandern, p. 49.

أحمد عزت عبد الكريم، تاريخ التعليم في مصر من نهاية حكم محد علي إلب أوائل توفيق 1848-1882، ج 2،(مطبعة 9

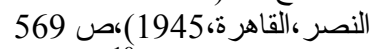

الياس الأيوبي، تاريخ مصر في عهُ الخديوي إسماعيل باشا من سنة 1863 البي سنة 1879 ، المجلا الأول، (مكتبة مدبولي، القاهرة، 1996)، 10 ص ص 234

أحمد عزت عبد الكريم، تاريخ التعليم في مصر من نهاية حكم محد علي إلب أو ائل توفيق 1848- 1882

569 ص،
} 
As a result of the French-Prussian war (1870-1871), Khedive Ismail declared an order of teaching German language inside Egyptian schools, this order affected the students of Madrast El Lesan Al Masry El Qadeem widely, who were the responsible for teaching German inside the schools as they were the first who learned German. In 1871 the Egyptian government asked the Swiss Dor Bek, the inspector of Diwan El Madares, to present a final report about the level of the students of Madrast El Lesan Al Masry El Qadeem, he visited the school in the beginning of 1872, and he presented a shocking report he stated in his report the following" the Egyptology school consisted of three European teachers for teaching the Ancient Egyptian history, Coptic language and German, and the number of the students is few and are Incompetent for studying, they have not any historical or philological backgrounds, as far as asking them for guarding the museum or site inspectors". ${ }^{12}$

As a result of his report in the mid of 1872, six students left the school including Ahmed Kamal, some of them were appointed as translators in the civil offices, others were appointed as German teachers. ${ }^{13}$

It is worthy of mention, here that the French Mariette began to worry that the Khedive might have a secret plan to appoint in his museum native official's familiar with hieroglyphic studies. He thus ordered the museum attendants not to permit any Egyptian student to copy hieroglyphic inscriptions. In fact, this was unbelievable act from a feigner to an Egyptian. The school was closed after Brugsch's departure, but despite this two of its students were appointed to the Antiquities Service. They were Ahmed Naguib and Ahmed Kamal ${ }^{14}$, and they contributed widely to Egyptology. ${ }^{15}$

\section{Its Graduates}

The fate of the graduates from Brugsch's school of Egyptology in Cairo illustrates both the indigenous intellectual interest in the pharaonic and Coptic heritage and the lack of support for such endeavors. ${ }^{16}$

Although the school did not last for long, a number of its graduates contributed in the movement of the historical works, they added a lot for the Arabic library with a number of books in ancient

\footnotetext{
12 James Heyworth Dunne, An Introduction to the history of Education in Modern Egypt, (Luzac and company, London, 1939), p. 354-355.

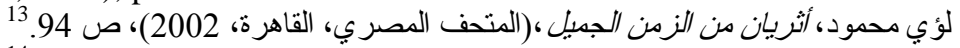

14 Ahmed Kamal is a pioneer Egyptian archeologist and Egyptologist he attended the Mubtadayan and Tajihizia school. Then studied with Brugsch at the first school of Egyptology in Cairo, he became a secretary interpreter in the Antiquities service and later assistant curator of the Egyptian museum, for which he translated guidebooks into Arabic in 1892-1893 and 1903. He conducted minor excavations throughout Egypt. Because Egyptology was dominated during his life time by Europeans he never received the honors that he might otherwise have earned.

${ }^{15}$ Elliott Colla, Conflicted Antiquities, Egyptology, Egyptomania, Egyptian Modernity, (Duke University Press, 2007), p.142.

${ }^{16}$ Neil Asher Siberman (editor in chief), The Oxford Companion to Archeology, vol.1, (Oxford University press, 2012), p. 482.
} 
Egyptian history and archeology, Ahmed Kamal who was one of its students was the first Egyptian who present his own philosophy in hieroglyphics and its grammar. ${ }^{17}$

Ahmed Naguib was appointed as director of Egyptian antiquities institution, he founded a newspaper called Al Manzom, with many books describing the monuments of Upper Egypt. Hussein Zaki also wrote books about Islamic history. It appeared that the most important matter here is that for the first time the Egyptians wrote about the ancient history, and cared for their monuments.

Al Tahtawi wrote the history of Ancient Egypt in Arabic, and Mubarak's topographical encyclopedia Al-Khitat Al- Tawfiqiyya paid great attention to the ancient sites and its monuments. Al Ahram newspaper which is the leading newspaper in Egypt till now, choose the pyramids for its name and every postage stamp used from 1867 to 1914 projected a pyramid and the sphinx as symbols of Egypt. ${ }^{18}$

Two European- dominated; earned societies emerged in Egypt as assembly of archeological discussion, the Institut Egyptien founded in Alexandria in 1859 and to a lesser extent the Khedival Geographical society established in 1875 in Cairo to foster Ismail's African empire, supplemented the museum and Antiquities service in dissemination the fruits of Egyptology. Members of these societies joined the International congress of Orientalists and geographers which began meeting in Europe in $1870 .^{19}$

\section{Madrast Alathar Altarekheia Almasria (Egyptian Historical Monuments' School)}

In 1881 Maspero, the director of the Antekhana, asked the government for five hundred pounds to establish a school for teaching archeology ${ }^{20}$, as they were in a bad need for this type of experts that they can depend on them during excavations in the archeological sites, because of the increase of the excavations in the site and the high cost of foreign experts. They decided to establish a school for teaching history and archeology and it was named "Madrast Al Athar Al Tarekhia Al Masria, but because of the bad economic status they did not construct it as a separate building, they attached it for the Antekhana.

\footnotetext{
${ }^{17}$ He has a dictionary for the ancient Egyptian language see: أحمد كمال، معجم اللغة المصرية القديمة، عدة أجز اء، (المجلس الاعلئ الأعلي للآثار ، القاهرة، 2002)

${ }^{18}$ Donald Malcolm Reid, Whose Pharaohs? Archeology, Museums, and Egyptian National Identity from Napoleon to World War I, p. p. 95.

${ }^{19}$ Donald Malcolm Reid, Whose Pharaos?: Archeology, Museums, and Egyptian National Identity from Napoleon to World War I, p. p. 96.

بيان مقدم من نظارة الأشغال إلي مجلس النظار بالمصاريف اللازمة لإنثاء مدرسة للآثار المصرية(وثائق مجلس الوزر اء، أثغال عمومية، 20 كود أرشيفي 0075-007-001861-0018)، 16 أكتوبر 1881
} 


\section{Its students}

The school was for teaching just five students, they appointed four Egyptian teachers inside the school Ahmed Kamal for Ancient Egyptian language, Mohamed Diab for Arabic; Ebrahim Hussein for hand writing, Khalifa Effendi for math. ${ }^{21}$

The number of the students were not sufficient, so they decided to add ten other students for the school. Regarding the system inside the school it was obligatory for the students to have their accommodation inside the school, the school presented them meals, cloth, and all their needs for studying, in addition of a monthly salary 15 piaster for each student. ${ }^{22}$ worth mentioning that the director of this school was Ahmed Kamal pasha who graduated from Madrast Ellsan El Masry Al Qadeem.

The study in this school continued till 1885, then Maspero presented a note for the ministry of public works to appoint the graduates of this school as inspectors in the archeological sites. He presented a demand also of closing the school and turn its financial allocations as salaries for these graduates, this is because he did not want to overload the budget of the ministry, also he was not in a need for this school, as a result the ministry accepted his demand and they closed the school and appointed its graduates as archeological inspectors. ${ }^{23}$

\section{The French institute for Oriental Studies (Institut Francais d'Archeologie Orientale IFAO)}

It was one of the most important institutions who worked in the archeological field in Egypt, it was called as the French school of archeology, and its name changed on 17 May 1898 to be The French institute for Oriental Studies ${ }^{24}$. It was the idea of the French Chancellor in Egypt Baron, to establish a French educational center for Egyptology. Also, the French writer Renanet supported this idea, the school was established in 1881 after the death of the famous explorer Mariette. The director of this school was Emile Chassinat who decided to attach a printing house for the school ${ }^{25}$ . this to publish all their excavations and scientific research as a kind of finding a financial support for their work in Egypt. They worked not only in the field of Egyptology but also for Islamic and Coptic monuments.

This school as it was called, was not on the form of the previous two schools for teaching Egyptology, but it was a place which cared about Egyptology and excavations in Egypt. Its existence in Egypt during this era was a very important step to increase the Egyptian interest in searching for the secrets of the ancient Egyptian civilization.

\footnotetext{
مذكرة نظارة الأشغال بشأن ترنيب خدمة مدرسة الآثار (وثائق مجلس الوزر اء، أثغال عمومية، كود أرشيفي20075-0002-035186)، 15 فبر اير 1882.

مذكرة من نظارة الأشغال بشأن زيادة أعداد الدارسين في مدرسة الآثار بالأنتكخانة(وثائق مجلس الوزر اء، أشغال عمومية، كود أرشيفي 22

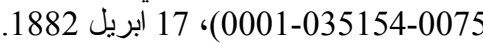

قرار إلغاء مدرسة الآثار التاريخية والتعديلات الخاصة بكادر المتاحف،(وثائق مجلس الوزراء، أنغال عمومية، كود أرشيفي 0075-23 (035309)، 4 فبر اير 1886 (2002

روبيير سولييه، مصر ولع فرنسي، ت لطيف فرج، ( الهيئة المصرية العامة للكتاب، القاهرة، 2002)، ص 238.

${ }^{25}$ Anniversaire de l'Institut Francais(IFAO),p.9.
} 
The school cared about archeological missions, it had a large number of Egyptologists like Maspero, Aures, Philipte Viry, Bouriant, Victor Loret, Grebaut, Bergmann, Amelineau, the Egyptians were not a way from this school but they attached to it with their research like Ahmed Pasha Kamal and Mohamed Effendi Shaban. The school had excavations in Delta between 18931894, and in 1896 it had excavations in Qurnah in Upper Egypt. The school also funded many excavations in Egypt, like the excavations of Shaban for the tombs of the $19^{\text {th }}$ dynasty in Assuit in a village called Al Khawaled. ${ }^{26}$ At the end of the $19^{\text {th }}$ century the French Institut had a large library with 40,000 books, till nowadays it is considered as the destination for the researchers.

\section{Maktab Sondok Estkshaf Masr (Egypt Exploration Fund)}

The British and the French were rivals along modern Egyptian history, they did not want to leave the excavations and the research projects for the French so they decided to construct the Egypt Exploration Fund (EEF).

The British author and traveler Amelia B. Edwards asked for building such institution after her journey in the Nile which was published in a book called A Thousand Miles Up the Nile. This to protect the Egyptian monuments and to reveal the secrets of its civilization. ${ }^{27}$

Amelia succeeded finally in the matter, in 1882 they established it in London, but they construct a small office of the Egypt Exploration fund in the British embassy in Cairo ${ }^{28}$. The aim of this exploration fund was to support excavations in Egypt and to have an archeological survey for both Egypt and Sudan. At its start, its efforts were concentrated in the Delta in 1883 from the explores were Petri and Neville, and in 1893 they started exploring in Upper Egypt exactly in Thebes. Salama Musa a Copt who went on to have a notable career as a socialist writer was embarrassed to show his ignorance of the pharaonic past while he was visiting Europe at the turn of the century, he had graduated from secondary school and felt that the Egyptian school system now thoroughly under the British control avoided the teaching of ancient Egyptian history for fear that such information would stimulate local national pride and a desire for independence. ${ }^{29}$ In 1900 the Exploration fund lost its position and Ahmed Kamal tried to establish a national school for exploring and teaching Egypt's monuments.

\section{The Higher Training College}

When Ahmed Kamal was assigned to join French archeologist's excavations in the Delta and Upper Egypt, he assiduously documented his work. No fewer than 29 articles in French appeared in the Annales du Service des Antiquities de l'Egypte(ASAE) the official publication of the antiquities service. Kamal set about translating works on Egyptology into Arabic with the aim of encouraging Egyptians to take an interest in their heritage. Kamal organized popular lectures in 1908 he began to teach the history of ancient Egypt at the recently founded Egyptian university.

${ }^{26}$ Chapan,M., Un Tombeau de la XIX Dynastie a El- Khawaled, Annales, Tome II, (IFAO, Le Caire, 1901), pp.137-140

اميليا ادو ارز، رحلة الألف ميل، ت إبر اهيم سلامة، (الهيئة المصرية العامة للكتاب، القاهرة، 1997)

${ }^{28}$ The Egypt Exploration Society, World Archeology, Issue 22, 2007, p.102

${ }^{29}$ Donald Malcolm Reid, Indigenous Egyptology. The Decolonization of a profession, journal of the American oriental society, 105,1985, p.181 
He found it humiliating that the archeological missions were directed by foreigners who were digging up objects in his country that related to his own heritage but not publishing their findings in his native language, "how could Egyptians take an interest in their ancient culture if there were no books to enlighten them", he reasoned. ${ }^{30}$

In 1909 when an archeological school opened in Athens ${ }^{31}$ Kamal saw a chance to press for the opening of such specialized institution in Egypt. It was not enough to give a few courses on ancient history at university level, Egyptians need more specialized studies and an opportunity to be trained in archeological technique.

He began to echo Mustafa Kamal call "Egypt for the Egyptians" with his own "Egyptology for Egyptians". Kamal decided to approach the head of Diwan Al-Madars(council of schools), and try to convince him of the need to found a school Egyptology in Egypt, the response was more positive than he hoped, he was advised to refer to Ali Mubarak and lost no time in doing so. Kamal presented his credentials assured the minister that he himself could direct a modest school at minimal cost, and mentioned that qualified students could then be appointed as inspectors at archeological sites. $^{32}$

This time he made a direct appeal to Saad Zaghloul, and the higher training college was founded in 1910, the first class graduated in 1912. It was a private secular institution initially housed in the rented first floor of the Gianaclis mansion near the British embassy in Garden City. The curriculum included literature, history, and philosophy, Kamal gave course of ancient history and also conducted field trips. ${ }^{33}$

\section{Its graduates}

Unhappily, Maspero considered the graduates unqualified to join the Antiquities service because they were not affiliated with an academic institution and because they lacked the necessary linguistic skills. Like Kamal's first small school of Egyptology in Bulak, the higher training college was desired for a short time. It closed with the outbreak of World War I in 1914, and the students fell back on secondary school.

In 1914, he tried to persuade the antiquities service and its French director Pierre Lacau to begin training more Egyptian students Lacau replied that few Egyptians besides Kamal himself took much interest in the pharaonic past, Kamal replied" Ah M. Lacau, in the sixty-five years the French have directed the service, what opportunities have you given us". ${ }^{34}$

The process of study was discontinued and obstacles were placed in the way of the development of later indigenous school of Egyptology for many reasons, the main reason was the desire of early western Egyptologists and others to keep Egyptians out of Egyptology by discouraging them

\footnotetext{
${ }^{30}$ Jill Kamil, Labib Habashi. The Life and Legacy of an Egyptologist, (American University in Cairo press, 2007), p. 29

31 Vasileios Petrakos, The History of Greek Archeology, Panos Valavanis(ed.), Great Moments in Greek Archeology, (Kapan, Athens, Greece, 2007), p.29.

32 Jill Kamil, Labib Habashi. The Life and Legacy of an Egyptologist, p. 29

${ }^{33}$ Michael Wood, the use of pharaonic past in Modern Egyptian nationalism, Journal of the American Research Centre in Egypt, vol.35, 1998, p. 182.

${ }^{34}$ John A Wilson, signs and wonders upon Pharaoh: A History of American Egyptology, (Chicago, 1964), p.192.
} 
from participation and study, thus leading to their marginalization and to inevitable western dominance of the subject. Another reason for the exclusion of Egyptians may here been the desire to claim ancient Egyptians as proto Europeans by showing that only Europeans were interested in the study of their history. ${ }^{35}$

\section{Egyptology Program at The Higher Teachers College}

The Egyptian educators jostle to repair the neglect of ancient Egypt inside the schools, the Milner mission in 1920 had permitted that neglect in an astonishing understatement some teaching on the subject which should include at least a few lines of ancient Egyptian history should be part of the subjects at least in the secondary schools, the ministry of public works which was called the Antiquities service transferred to the ministry of education in 1929 this transformation prove the awareness of the value of Egyptian antiquities. ${ }^{36}$

It had been westerners who forced the three schools of Egyptology with which Kamal had been associated to close. In 1921 Kamal had persuaded Sultan Fuad to arrange for the selection and training of three Egyptian assistant curators for the museum. Meanwhile Egypt's fourth school of Egyptology had begun molding, a third generation of Egyptian Egyptologists, in August 1923 founded Egypt's fourth school of Egyptology at the Higher Teachers College, Kamal was to have been its director, like its prewar predecessor, the school began as a section in the Higher Teacher's college. Kamal died the same day, but the school went ahead and opened its doors a few months later. The private Egyptian University also offered its first course on the ancient Egyptian language in 1924; it is unclear whether this was combined with the Teachers College course. with Kamal's death European professors were the only option, they directed the program till World War II. $^{37}$

Two weeks after Zaghlul's Wafdist cabinet took power in 1924, the Egyptology department of the private Egyptian university began shaping the third generation of Egyptian Egyptologists. For the first two years, the program met on the premises of the Higher Teachers College, holding classes in the evening to accommodate working students. Arabic and French were the languages of the institution. In the fall of 1925, the program became the department of Archeology in the faculty of arts of the new state run Egyptian university. ${ }^{38}$

The Higher Teachers College provided critical training for a whole generation of future Egyptologists, historians, geographers, and in the case of the prime minister Nuqrashi politicians. The post war independence movement derailed the university commission and in 1925 with the wafd in eclipse, king Fuad and the liberal constitutionalists designed the new Egyptian university.

35 Okasha El Daly, Egyptology: the Missing Millennium Ancient Egypt in Medieval Arabic Writings, ( Rutledge, London, 2005), p. 4.

${ }^{36}$ Donald Malcolm Ried, indigenous Egyptology. The decolonization of a profession, journal of the American oriental society, vol.105, n. 2, 1985, p, 239

${ }^{37}$ Donald Malcolm Ried, indigenous Egyptology. The decolonization of a profession, journal of the American oriental society, vol.105, n. 2, 1985, p, 241.

${ }^{38}$ Jason Thompson, Wonderful Things. A History of Egyptology. the Golden Age 1881-1914, vol 2, (American university in Cairo press, 2015), p. 117-118. 
The Egyptological section at the Higher Teachers College was upgraded into a department in the new faculty of Arts. ${ }^{39}$

Golenischeff V., Russian expatriate, taught both courses. The Egyptian University took over the Egyptology program in its Department of Antiquities (later the Faculty of Arts) in 1925. The first graduated class with a license was in 1928. Many years later this Department transferred to a graduate level institute which offered a diploma at the end of its program which reached to three years. Separate departments of Egyptology and Islamic archeology were set up. The university's Egyptology program was headed by foreign professors, but the national independence and control of Egyptology were in sight also. ${ }^{40}$

Newberry succeeded Golenischeff in 1929. Newberry retired in 1933, and Austrian Egyptologist Hermann J. succeeded him from 1934 to 1939. they were qualified Egyptologists who served Egypt very well. Vikentiev V., a Russian who taught in the program many years without obtaining a professorial chair. Selim Hassan headed the Egyptianizing movement, firstly at the university, and finally at the Antiquities Services. He returned from Paris in 1927 with higher diplomas. ${ }^{41} \mathrm{He}$ received his doctorate from Vienna University in 1935 at fifty. Selim Hassan taught inside the university from 1928 till 1936, he is the first Egyptian full professor in Egyptology. ${ }^{42}$

Selim Hassan served for three months with Junker's Austrian expedition at Giza Pyramids, then he began digging nearby under the Egyptian University sponsorship. he had a publicity glow, and he caught the attention of the Egyptian press. He wrote "It is indeed a matter of deep regret for us, Egyptians, that the monuments should be ours and the history should be ours, but that those who search for these monuments and those who write books on the history of ancient Egypt should not be Egyptians". ${ }^{43}$ Selim Hassan opened new era, in which the excavation for monuments and the writing of the history of ancient Egypt transferred from the foreigners' hands to the Egyptians' hands.

Selim Hassan left the university in 1936 for the Egyptian Museum and continued for his excavations till 1939. As Selim Hassan, Sami Gabra went to Liverpool and Paris in 1920 for studying Egyptology, then he returned to the museum and teaching in the university ${ }^{44}$. Junker's departure in 1939 left the Institute of Archeology's chairmanship at the university vacant. Long negotiations for an European successor failed, and finally Gabra became the first Egyptian chairman. Beginning with the graduating class of 1928, Egypt was finally producing a supply of its own archeologists. This third generation included Ahmad Fakhri (1905-1973), Girgis Mattha (d. 1964 or 1965), and Labib Habachi (1906-1984) in the Class of 1928 alone. Ahmad Badawi, the future president of Ayn Shams university ${ }^{45}$.

\footnotetext{
جامعة القاهرة، الكتاب الفضي لكلية الاداب 1925-1950.

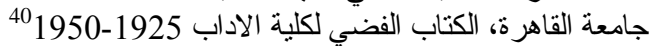

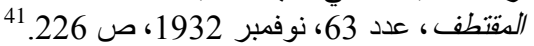

42 Donald Malcolm Reid, contesting Antiquity in Egypt. Archaeologies. Museums, the Struggle for Identities from World War I to Nasser, (AUC press, Cairo, 2015), p..118

${ }^{43}$ Donald Malcolm Ried, indigenous Egyptology. The decolonization of a profession, journal of the American oriental society, p.241.

${ }^{44}$ Jill Kamil, Labib Habashi. The Life and Legacy of an Egyptologist, p. 136

${ }^{45}$ Donald Malcolm Ried, indigenous Egyptology. The decolonization of a profession, journal of the American oriental society, p.241.
} 
In 1930 Creswell took up the new chair of Islamic archeology and a graduate level institute of Archeology replaced the undergraduate department. Despite Franc's long archeological presence in the Antiquities service and IFAO, the British managed to exclude them from university chairs in archeology, the British had no objections to letting Golenischeff occupy the Egyptology chair at first. Labib Habschi a member of the third generation that began graduating from the Egyptian university in 1928 had begun archeology at the Higher Teachers College and followed the program into the university. He regretted never having met Ahmed Kamal, he studied hieroglyphics with Golenischeff, Arabic was by Taha Hussein, Coptic and little demotic with George Sobhy and Ahmose Labib. ${ }^{46}$

Concerning Women Egyptology Education Mille Afifa Iskander spoke at the retirement dinner hosted by Rector Lutfi Al Sayid for Golenischeffin 1928. She had been allowed to attend classes as an exception but not to earn a degree, and she seized the occasion to plead for coeducation, the first women entered the state university the following year though not in Egyptology, the first women in Egyptology graduated in 1941 followed by three more in $1949 .{ }^{47}$

Both Abd al-Muneim Abu Bakr, and Zaki Sa'ad were graduated in 1930. Abu Bakr took his doctorate from Berlin and Mattha from Oxford. The Egyptian University awarded its own Egyptology doctorates started in 1942, thirteen Egyptians received them between 1942 and 1966. The archeology program expanded in 1960 and became a separate independent Faculty of Arts in $1970 .^{48}$ Meanwhile the proliferation of Egyptian universities began to make more teaching jobs available to the rapidly growing numbers of Egyptologist graduates.

\section{Conclusion}

The educational Egyptology institutions were known from Mohamed Ali's era; many trials were made by Al Tahtawi in translating the history of Ancient Egypt from the French into Arabic to reach the Egyptians. The real start for educational Egyptology institutions in Egypt was during the era of khedive Ismail by Madrast El Lesan Al Masry Al Qadeem. Along the history of modern Egypt there were many trials to prevent constructing such institutions in Egypt. The subjects which were taught in all Egyptology educational institutions were Hieroglyphics, Coptic language, Ancient Religion, and sometimes German. The teachers in these institutions were foreigners along the modern history, except for Ahmed Kamal pasha who contributed widely in constructing an institution for teaching Egyptology for the Egyptians, also Selim Hassan taught Egyptology at the university and he was the first Egyptian full professor in this field. These institutions had few numbers of students did not exceed 15 students, this mean that this type of education were not familiar among the Egyptians. The graduates of these institutions faced many obstacles by the Europeans who prevented them in joining the archeological excavations, but despite these obstacles many of them were appointed as archeological inspectors and they contributed widely in the field by writing a number of Arabic books about Ancient Egypt and its history. The course of

46 Donald Malcolm Reid, " Nationalizing the Pharonic past, Egyptology, imperialism, and Egyptian Nationalism 1922-1952", in, Rethinking Nationalism in the Arab Middle East, James Janloski and Israel Gershondi(ed.), (Columbia University press, 1997), p. 127.

${ }^{47}$ Jason Thompson, Wonderful Things. A History of Egyptology. the Golden Age 1881-1914, p. 127.

${ }^{48}$ Donald Malcolm Ried, indigenous Egyptology. The decolonization of a profession, journal of the American oriental society, vol.105, n. 2, 1985, p, 242. 
Egyptology inside the Egyptian university was directed by European professors till the second world war. The first graduated woman in the field was in 1941.

\section{Bibliography Unpublished Documents}

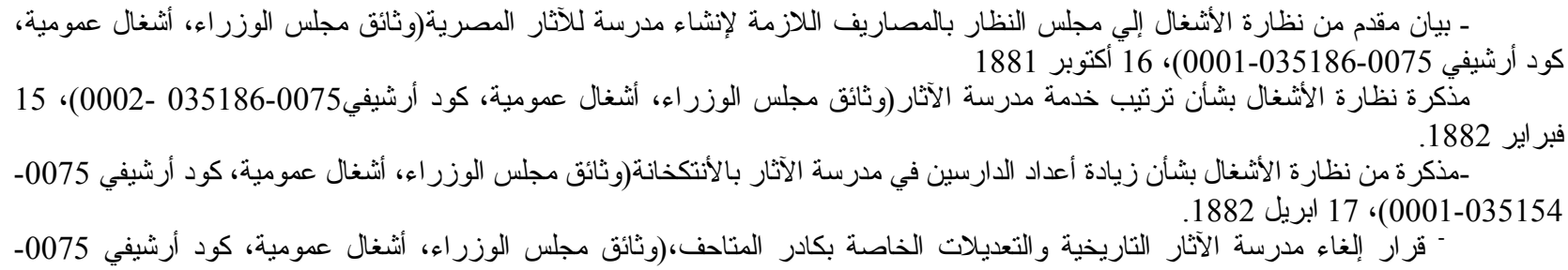

\section{References}

Anniversaire de l'Institut Francais d' Archeologie Orientale(IFAO), (Le Caire, 1981)

Chapan,M., Un Tombeau de la XIX Dynastie a El- Khawaled, Annales, Tome II, (IFAO, Le Caire, 1901).

Charles Kurzman(ed.), Modernist Islam 1840-1940, (Oxford University press, 2002

Donald Malcolm Ried, indigenous Egyptology. The decolonization of a profession, journal of the American oriental society, vol.105, n. 2, 1985. 1952", in, Rethinking Nationalism in the Arab Middle East, James Janloski and Israel Gershondi(ed.), (Columbia University press, 1997).

, Whose Pharaos?: Archeology, Museums, and Egyptian National Identity from Napoleon to World War I, (University of California press,2002 ).

contesting Antiquity in Egypt. Archaeologies. Museums, the Struggle for Identities from World War I to Nasser, (AUC press, Cairo, 2015).

Elliott Colla, Conflicted Antiquities, Egyptology, Egyptomania, Egyptian Modernity, (Duke University Press, 2007).

Heinrich Brugsch, Mein Leben Und Mein Wandern,(Berlin, 1894).

James Heyworth Dunne, An Introduction to the history of Education in Modern Egypt, (Luzac and company, London, 1939).

Jason Thompson, Wonderful Things: A History of Egyptology 1 from Antiquity to 1881, vol.1, (A.U.C press, Cairo,2015)

, Wonderful Things. A History of Egyptology. the Golden Age 1881-1914, vol 2, (American university in Cairo press, 2015)

Jill Kamil, Labib Habashi. The Life and Legacy of an Egyptologist, (American University in Cairo press, 2007).

John A Wilson, signs and wonders upon Pharaoh: A History of American Egyptology, (Chicago, 1964).

Michael Wood, the use of pharaonic past in Modern Egyptian nationalism, Journal of the American Research Centre in Egypt, vol.35, 1998.

Neil Asher Siberman (editor in chief), The Oxford Companion to Archeology, vol.1, (Oxford University press, 2012). 
Okasha El Daly, Egyptology: The Missing Millennium Ancient Egypt in Medieval Arabic Writings, (Rutledge, London, 2005).

The Egypt Exploration Society, World Archeology, Issue 22, 2007.

Vasileios Petrakos, The History of Greek Archeology, Panos Valavanis(ed.), Great Moments in Greek Archeology, (Kapan, Athens, Greece, 2007).

Youssef M. Choueiri(ed.), A Companion to the History of the Middle East, (Blackwell Publishing Ltd., Oxford, 2005).

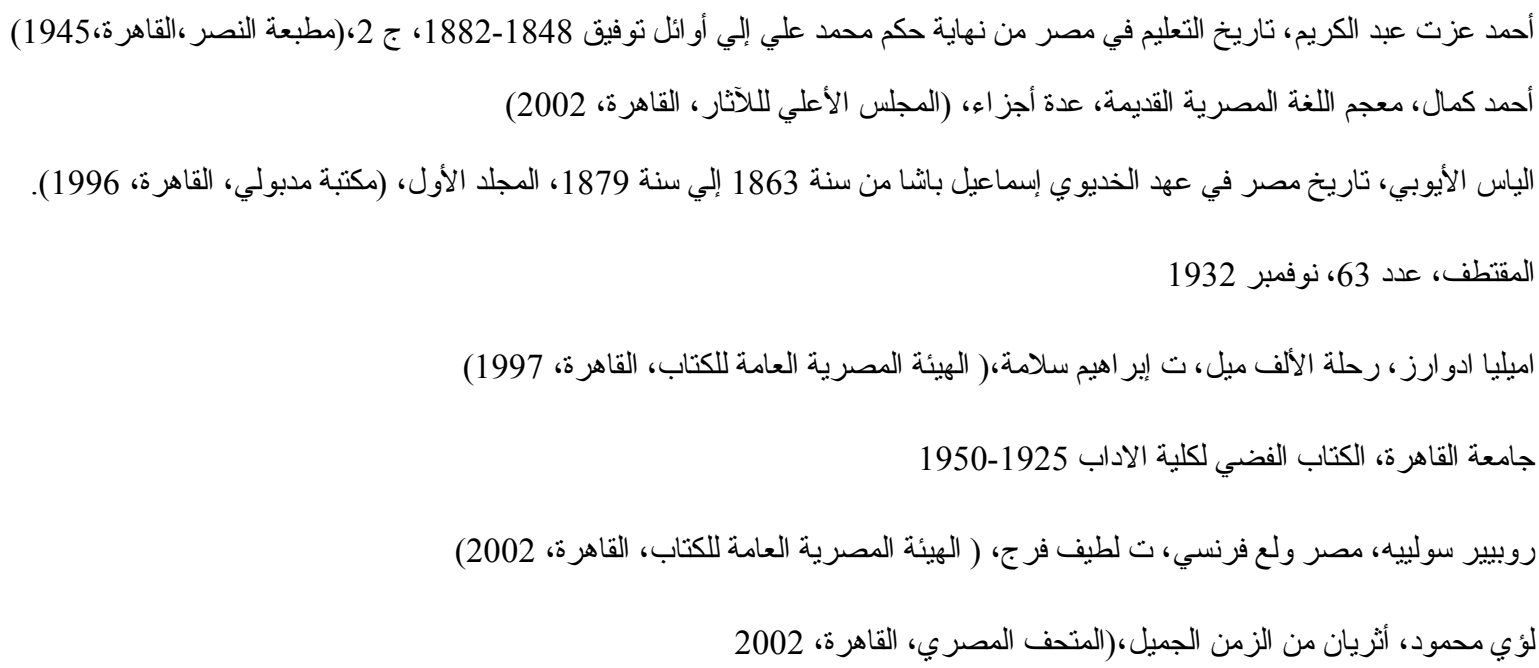

